\title{
Folk Culture of Kang Tou Stone Lions of China
}

\author{
Jing ZHANG \\ College of Art and Design of Xi'an University of Technology, ShaanXi, China \\ jingzhang@xaut.edu.cn
}

Keywords: ShaanXi of China, Kang Tou stone lions, Philosophy,Folk culture.

\begin{abstract}
The Chinese people really value Kang Tou stone lions because they are auspicious animals in Chinese folk culture. This paper will analyze the distinctive national character and the regional folk culture features in order to reveal the Kang Tou stone lion as the cultural symbol about the quality of life.
\end{abstract}

\section{Introduction}

The lion is a special animal to Chinese people. It is interesting to note that no one has discovered the definitive date when the lion came into China. It is only known that the first lion was presented to China during the Eastern Han Dynasty by a king from the Western Regions. At this same time, Buddhism also arrived into ancient China. Sakyamuni, the founder of Buddhism, pointed to Heaven with one hand and with the other hand pointed to land, roaring like a lion [1]. So, the lion became a divine animal which can protect the truth and keep off evils. The stone lion was often placed at the gates of imperial palaces and mausoleums of king because it was regarded as power symbol. Meanwhile in Chinese folk culture, the lion developed into a symbol of bravery and good luck. For these reason, the Kang Tou stone lions were popular with people and became a major part of celebrations and festivals in daily life.

Sculpted lions, either male or female, can often be seen in the Kang Tou or bed in the ShaanXi province. The male lion is normally sculptured with an stony egg in his mouth and his left paw resting on a ball while the female with her right paw fondling a cub [2].These lions are sitting on the bed as usual, so they are called Kang Tou stone lion (Figure 1).

The artist created all kinds of stone lions north of Shaan Xi province. Some of the stone lions are appear alone while others are paired. The largest measures approximately $25 \mathrm{~cm}$ in height and the smallest only about $3 \mathrm{~cm}$. These were made of the local bluestone material and are known as the Kang Tou stone lions as "god of life protection." They convey the message of "long life" and "good luck and happiness to you " (Figure 2) [1].

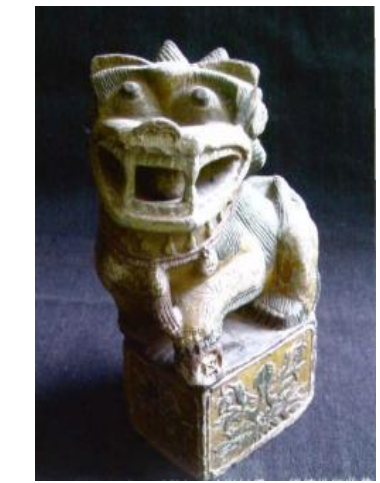

Figure 1: The male Kang Tou stone lion

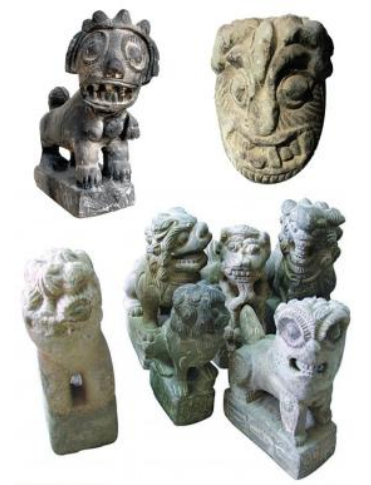

Figure 2. The Kang Tou stone lion 


\section{The Folk Culture}

\section{Yin and Yang worship}

Yin and Yang were popular in the culture of ancient China. LaoZi is a famous Chinese philosopher who taught that "everything negative is Yin; positive is Yang" ${ }^{[3]}$. The ancient minds of China thought that everything in the world was combined by the Yin and the Yang concept which gradually formed the Chinese traditional thinking. Yin and Yang philosophy were directly reflected to carving of stone line, so, Kang Tou stone lions have spirit of life and can defend the natural thing.

For example, when the crafter was carving, they chose the stone first and placed them into clear water immersion in order to combine the Yin and the Yang. After that step, they would choose a lucky day to start carving, which must be done at night when the sky has many stars, The carving took about one hundred days because people believed that god didn't have a shadow and was invisible, accept at night. When working on the Kang Tou stone lion, the time must be when the stars of the night are shining. At the same time, people also think "the lion" represents many good things such as luck and protection of family. In the region north of ShaanXi during ancient times the people often needed to adjust the Yin and Yang, and bless them safety.

\section{God Worship}

When Buddism came into China, the lion represented a god who had the strength to destroy the evil of people.

First, it was described as a fairy tale about Kang Tou stone lion. Long long ago, there was a devil fox in the north of Shaan Xi province. The fox often ate the villagers. one young man named QiangGuo that He bravely became a lion and ate the fox. From then on, he lived in the forest to protect the people. Thus the lion become a symbol to protect the people when they meet difficulty and natural disasters.

Second, with the development of folk customs, the Kang Tou stone lion functions as a fire god because of its placement in the kitchen. The close proximity to where the people where in the house allowed the lions to be physically closer to the daily function. The lion became even more powerful. For example, the book <<folklore document of ShaanXi >> wrote, it is on the 23 December of lunar every year, the people will clean the house and offer bread, sugar, some candle, fruits and so on to fire god at the kitchen ${ }^{[4]}$. let the fire god bless health and happiness for whole family members. Thus the Kang Tou stone lions and god of kitchen evolved into one powerful god.

Some of the Kang Tou stone lions have other titles such "Fu god", "Paul of god", "the life of god", in different festivals.

\section{Reproduce Worship}

The belief in the need for fertility and development has been in existence since the beginnings of history. This belief has been strongly associated with and merged into Chinese culture, which has been in development for thousands of years.

In ancient times, people were afraid of death and yearned for life, thus, in order to be rid of the scare of death and pursue the eternal life, people started to deify certain objects or animals as symbols of eternal life because they believed that fertility and development of life are tightly associated with the deific symbols. In addition, people also think they can have eternal life only through reproduction. So, stone lions are one of the symbols which have the significance of human reproduction and development, as well as a representation of Chinese folk culture.

First, Kang Tou stone lion purpose was to protect the baby. A "birthday" is very important as a festive occasion in the life and customs of ShaanXi, along with crown, courtesy and wedding ${ }^{[5]}$. They, together, are the most important events in one's life according to traditional customs of China. The soul is not complete when the baby is born; the soul could easily be easily be destroyed by evil. To prevent this, the family places the Kang Tou stone lion in his house to protect baby, hoping the baby will grow healthy. At the same time, "the lock" ceremony was produced ${ }^{[6]}$. Then the family invited a 
wizard and the whole family would sit on the Kang Tou (bed) and perform a "ceremony" for stone lions. The family be tie a red line from the baby to the stone lion. The wizard read incantations to pray to the gods to bless for baby's good health. It could give person a kind of solace and hopes on the minds, like incantation of Harry Potter to protect children.

Kang Tou stone lion Passed from generation to generation, the lion served grandpa and served the grandson and became god of the family. Some stone lion not only bless the family life and it will also could be "borrow" by relatives ${ }^{[7]}$. If the daughter married, the parents will give her a lion to protect her family.

Second, Kang Tou stone lion's other purpose was to direct good to the baby. Some of the lions are shown standing up on model and legs decorated with "Hui Xing" pattern, then it is a symbol of female reproductive of symbols with roundness or half circle at the bottom. Some of the Kang Tou stone lions engraved "fish" on the base, which refers to its strong power, just like a fish's fertility. Some stone lion are engraved with lotus or lotus doll, a system using a harmonics form to express fertility. Therefore, the Kang Tou stone lion had original reproduction worship not only from model but also from custom culture and have been cared for mankind factor and established a set of new folk etiquette rules.

\section{Auspicious Worship}

Stone lions are particularly popular in ShaanXi province because of the significance of good luck, not only because of their modeling style and the popularity of the patterns of the decoration with the lions, but also people's psychological eagerness and ambitious to pursue the ideal life they want and is formed after long term social practice.

The first and the best known is that the Kang Tou stone lion showed abundant personification of modeling with exaggerated heads and downsized body which people liked and do not fear. For example, according to folk craftsmen: "model of stone lion is happy" ${ }^{[8]}$. Some of lions tilted head with the faces of horses or monkeys or with the bodies of tigers or goats. Some have open big mouths and often the stone lion has a ball in his mouth. The ball is a luck symbol which has the same sound (Qiu) in Chinese language. Some of the stone lions have human physical characteristics and facial expressions with joyful, angry, sad and other expressions. The model of lion is far beyond the reality the lion as is implied by the traditional culture of auspicious or as they represented people's spiritual world.

Second, people widely used some auspicious decorative, such as "HuiWen", "TaiJiWen". Its purpose was to pray for riches and health and to avoid disaster. On the base of carved "good luck and happiness to you ", "Fu", "god" luck words and so on, these words and lion together add more rich in the meaning of auspicious. Therefore, the stone lion is a lucky idea and a way to seek good fortune and happiness north of ShaanXi.

\section{Summary}

With the hundreds of years of inheritance, Kang Tou stone lions were gods of the people. And, although they were not placed in temples, people believed and depended on them because Kang Tou stone lion had unique models and messages which were reflected to people's mind. At the same time Kang Tou stone lions expressed people's aesthetics and philosophy. So, Kang Tou stone lions are excellent examples of national culture in folk art of ecology.

\section{Acknowledgement}

This research was financially supported by the National Science Foundation.

\section{References}

[1].Yu Ning, Hua Rong, "Folk Art Research of ShaanXi," No.01(1988): P 143-144 
[2]. Stone Lion In Front of an Official Residence No.o5 (2006)

[3]. Zhilin. Jin, Chinese folk arts, (2004) p6-10

[4]. Folklore Document of ShaanXi, No.77 (2000):

[5].Jing. Lv, "Research culture of ShaanXi,”XueLin, (2004):p 5-8

[6]. SuiDe library, folk custom, p12

[7]. Huaishui. Zhang, Folk Stone Lions, (2009):p56-60 